\title{
A selection of weather type classification systems and examples of their application
}

\author{
Katarzyna Piotrowicz ${ }^{1}$ (D) - Dominika Ciaranek ${ }^{1}$
}

Received: 22 October 2018 / Accepted: 24 January 2020 / Published online: 3 February 2020

(C) The Author(s) 2020

\begin{abstract}
The paper discusses a selection of the most popular systems classifying weather types found in climatological literature. The review focuses on the choice of meteorological elements and their value ranges as the differentiating criteria. Examples of the application of some of these systems are presented, as well as a number of possible analyses that could be attempted. In order to investigate this, use was made of 1961-2010 meteorological data from stations in Warsaw (Poland) and Cologne (Germany). It was found that the annual and long-term changes in the types of weather reflect the diversity and variability of the climate in both cities very well, and allow the stability (non-changeability) of weather to be quantified.
\end{abstract}

Keywords Weather types · Classifications of weather $\cdot$ Complex climatology $\cdot$ Stability of thermal conditions $\cdot$ Warsaw (Poland) Cologne (Germany)

\section{Introduction}

Any in-depth study of climatic conditions essentially requires an analysis of the frequency of occurrence of various weather situations, or types, and of their seasonal variations (Błażejczyk 1979). It is widely agreed that an alternative approach involving an analysis of individual meteorological elements fails to offer a full picture of the features of the climate being studied (Błażejczyk 1985; Woś 1999, 2010; Piotrowicz 2010). This approach lacks the crucial component of the mutual relationships between the meteorological elements. Indeed, it is their combined and comprehensive effect in a given geographical environment, which determines the type of climate.

Weather conditions have a significant influence on human activity. Complex climatological methods are used to determine their characteristics, which then find application in numerous areas of life and in the economy (Kozłowska-

Katarzyna Piotrowicz

k.piotrowicz@uj.edu.pl

Dominika Ciaranek

dominika.ciaranek@doctoral.uj.edu.pl

1 Department of Climatology, Institute of Geography and Spatial Management, Jagiellonian University, Gronostajowa 7, 30-387 Krakow, Poland
Szczęsna 1965; Hidalgo and Jougla 2018). This is because it is the entire complex of meteorological elements, rather than each element individually, that matters for human health and well-being, for the development of plant life and wildlife and for transport and industry.

The beginnings of complex climatology (derived from the Latin complexus meaning to embrace), date back to the 1920 s. The basics of complex climatology were laid down by Fedorov and his colleagues, including especially Chubukov (Kozłowska-Szczęsna 1965). The field saw particularly rapid development in the Soviet Union but also in the USA (Howe 1925; Nichols 1925, 1927; Switzer 1925). This shows that the search for methods that would link various meteorological situations in one weather type (or complex) has a long tradition (Błażejczyk 1985).

The term "weather type" is used in both complex climatology and in synoptic meteorology and synoptic climatology. Depending on the purpose of the weather type classification, they can be divided into two groups-(1) morphological (consistent with the premises of complex climatology, where weather type is determined on the basis of similar characteristics of the daily course of the values of selected meteorological elements) and (2) genetic (determined on the basis of the synoptic situation and/or atmospheric circulation types) (Kaszewski 1992). In the latter group, the performed classification results in the determination of "circulation" weather types (or synoptic/macrosynoptic weather types; see for 
example: Littmann 2000; Bissolli and Dittmann 2001; Sheridan 2002, 2003; Brown 2004, 2005; Boé and Terray 2008; Moron et al. 2008; Makra et al. 2009; Putniković and Tošić 2018; Schwander et al. 2017). Works drawing on genetic classifications (Philipp et al. 2010) will not be discussed in this paper, as they do not fit with the main purpose of the study, whose authors focused on weather types identified on the basis of morphological classifications.

As already mentioned, the first climate analysis based on a morphological classification was developed by Fedorov for Pavlovsk. The weather type for each day was described with quite a complex letter code including the values of the daily mean, maximum and minimum air temperature, the difference between current temperature and that on the previous day, relative humidity in $20 \%$ intervals and at 1 p.m., cloud cover, precipitation, wind direction and speed and state of ground. The initial version of this classification was later modified on numerous occasions, and since 1949 in literature it has most frequently been referred to as the Fedorov-Chubukov classification (Kozłowska-Szczęsna 1965). It identifies eight weather types each in the warm and cold seasons of the year on the basis of air temperature, cloud cover, relative humidity, precipitation and wind.

In the mid-1920s, morphological classifications of weather types were created in North and Central America as well. Howe (1925) distinguished 13 weather types in North America, taking into consideration 4 air temperature classes, 2 precipitation classes (instead of humidity and cloud cover, due to data collection difficulties) and 2 wind speed classes. Switzer (1925) relied on a similar weather type classification principle in Mexico. However, he distinguished 12, rather than 13 , weather types, using the same meteorological elements as a basis. In the same year, Nichols (1925) proposed a classification of as many as 720 different weather types in the USA. He distinguished 10 air temperature ranges, 6 humidity ranges, 4 wind speed ranges and 3 cloud cover ranges.

In the 1970s, climatology literature again started to refer to weather type studies based on morphological classifications. Worth mentioning is the work by Hufty (1971), who distinguished 19 weather types in Quebec and Montreal (Canada) on the basis of daily values of maximum and minimum air temperature and additional weather indices based on sunshine and precipitation. Besancenot et al. (1978) distinguished 8 weather types favourable for summer tourism in the Iberian Peninsula coastal areas on the basis of air temperature, relative humidity, sunshine and wind. Research based on this classification was continued by Alcoforado et al. (2004) and Andrade et al. (2007).

After a hiatus of a dozen years or so, when climatology literature was largely dominated by papers drawing on circulation weather types (Philipp et al. 2010), studies taking account of weather types identified in line with the tenets of complex climatology started to appear again. Worth mentioning are studies such as the one by Cantat and Savouret (2014) or Hidalgo and Jougla (2018). In the first one, the authors analysed weather types in France and identified 64 weather types, relying on four classes of cloud cover, four of wind speed, two of temperature and two classes of precipitation (Cantat and Savouret 2014). In the second paper, 10 weather types identified on the basis of the daily temperature amplitude $\left(\mathrm{T}_{\max }-\mathrm{T}_{\min }\right)$ and the daily means of specific humidity, precipitation, wind speed and direction were used to study the urban climate of Toulouse (Hidalgo and Jougla 2018).

After World War II, comprehensive climatology started to develop dynamically in Poland as well. Especially in the 1960s and 1970s, several weather type classifications were developed (both genetic and morphological ones). Among the most important ones were those devised by A. Woś between 1968 and $2010(1999,2010)$. As the premises of this classification were used in this paper, it was discussed at length in the next chapter ("Data and methods").

Morphological weather classifications are most frequently used for the general climatic description of a particular location (Cantat and Savouret 2014), but they have also been applied in bio-meteorological and bio-climatic studies, e.g. in the climate therapy of spa and holiday resorts or in agricultural climatology. The previously mentioned FedorovChubukov classification makes it possible to distinguish 3 weather groups: helpful, helpful with a restriction and unhelpful for climate therapy. Alcoforado et al. (2004) analysed weather types in connection with the visitor numbers in a tourist area of the Lisbon coast. For that purpose, the authors used classifications based on cloudiness ( 3 classes) and Physiological Equivalent Temperature indicator (3 classes).

In Poland, bioclimatic weather type classifications have been developed by authors such as Błażejczyk in his papers published between 1979 and 2004 (Błażejczyk 2004). The author's most recent classification, i.e. the biothermalmeteorological classification of weather, may be used for a detailed characterization of weather conditions, and also as basic information about the recreation potential of any area and/or period (day, month, season, year). In his classification, Błażejczyk (2004) took into account 7 types, 27 subtypes and 8 weather classes, relying on values of the thermal sensations, intensity of radiation stimuli, physiological strain, sultriness, daily amplitude of temperature, precipitation and snow cover (Błażejczyk and Matzarakis 2007).

Piotrowicz (2010) proposed another classification, building on the systems devised by Woś (1999) and by Błażejczyk (2004). The new classification was used to identify weather types in Krakow on every day of the 1901-2008 period. This data was used to analyse the city's climatic variability and to identify the beginning and end dates of climatological seasons. Since the classification system was built for the purpose 
of identifying seasons, the author selected air temperature ranges that were the closest to the threshold values commonly used for dividing the year into thermal seasons in Poland. The system by Woś (1999) met the criterion, and his ranges of air temperature values were adopted. According to Piotrowicz (2010), they best reflected the everyday variations in thermal conditions. Also, the threshold values adopted by Woś (1999) are commonly used in various studies on climate and bioclimatic conditions, as well as for identifying characteristic days, i.e. cold, ground-frost and hot days. Piotrowicz (2010) considered using cloudiness to identify weather types the way it had been done in the system proposed by Woś (1999). Eventually, however, she came to the conclusion that relative sunshine duration would better serve the purpose of her study. Precipitation is the final element of the weather type classification system proposed by Woś (1999). In her study, Piotrowicz (2010) modified this system by adding a day with more than $5 \mathrm{~mm}$ of precipitation alongside dry and wet days. The author added snow cover, thunderstorms and sultriness to her classification system in order to facilitate its intended use in identifying the timing of seasons and in determining the influence of the weather and climate on the environment and on humans (Piotrowicz 2010; Piotrowicz and Ciaranek 2014). Considering a recent string of atypical winters, the inclusion of snow cover could help to determine the beginning and end of such seasons. Snow cover and sultriness were also employed by Błażejczyk (2004) in his biothermalmeteorological weather classification. Thunderstorms, including precipitation, and sultriness can be used to assess the influence of weather on human health and well-being, as well as of plant phenophases and pollen seasons (Piotrowicz 2010; Piotrowicz and Ciaranek 2014). Altogether, 225 weather types were identified in Krakow during the period 1901-2008 (Piotrowicz 2010).

A special group consists of papers which present the relationship of weather as a complex of occurrence of several meteorological elements with atmospheric circulation, i.e. those that combine genetic and morphologic weather type classifications. This group includes publications by Maheras $(1984,1985)$, where the author compared the distribution of weather defined by 7 meteorological elements in 15 circulation types. This research direction was continued by Michailidou et al. (2009a, 2009b). To identify weather types, the authors used cluster analysis and meteorological data (air temperature, precipitation, relative humidity, wind speed and sunshine), as well as circulation data. In Polish literature, a similar approach was represented by authors such as Kaszewski (1992), Bielec-Bakkowska and Piotrowicz (2011), Piotrowicz and Szlagor (2013).

The study offers two purposes: methodological and cognitive. The first aim was to compare two weather classification methods and to show examples of their application. The other aim was to compare seasonal and multiannual fluctuations of weather conditions in 2 stations representing slightly different climate patterns: Warsaw (Poland) and Cologne (Germany) in the period 1961-2010.

\section{Data and methods}

The analysis was based on data from 1961 to 2010 from two meteorological stations located at similar latitudes: Warsaw $\left(52^{\circ} 09^{\prime} \mathrm{N}, 20^{\circ} 57^{\prime} \mathrm{E}, 106 \mathrm{~m}\right.$ a.s.l.) and Cologne ( $50^{\circ} 51^{\prime} \mathrm{N}$, $7^{\circ} 09^{\prime} \mathrm{E}, 92 \mathrm{~m}$ a.s.l.). The cities are also similar in size and population. Warsaw has an area of $517 \mathrm{~km}^{2}$ and is inhabited by approx. 1.7 million people, while Cologne has an area of $405 \mathrm{~km}^{2}$ and has 1.0 million residents (data from 2018). The distribution of the mean monthly air temperatures and precipitation at both stations in the multiannual period under study is presented in Fig. 1.

The data for Warsaw was provided by the Institute of Meteorology and Water Management-the National Research Institute, and that for Cologne was obtained from the European Climate Assessment \& Dataset (ECA\&D) (Klein Tank et al. 2002). They consisted of diurnal measurements of air temperature (maximum, minimum and mean; ${ }^{\circ} \mathrm{C}$ ), precipitation ( $\mathrm{mm}$ ) and cloudiness $(\%)$.

The examples of weather type classifications discussed in the previous chapter differed in terms of the selection of the meteorological elements and/or the number of ranges to which the values were classified. Finally, the classification by Woś (1999) (Table 1) was used in the present study. It draws on the basic and most frequently analysed meteorological elements.

In Poland, the best known, and the most popular, weather type classification system was proposed by Woś $(1999,2010)$ (Table 1). It provides a good characterization of Poland's climatic conditions and those of other regions in moderate latitudes areas, and has a universal nature.

Woś (1999) selected three meteorological elements for his system: air temperature (daily average, maximum and minimum), average daily cloudiness and the daily precipitation total (Table 1). He divided these values into 16 ranges (including 12 for temperature, 3 for cloudiness and 2 for precipitation) ending up with 66 basic weather types. The types are coded with numbers where the first digit (or first two digits in the case of the frosty weather type; symbol 10-12) denotes the thermal conditions, the penultimate digit gives information about the cloudiness, and the final one about precipitation (Table 1).

A total of 12 thermal weather types which were distinguished, which can be assigned to three groups: warm ( $\mathrm{T}_{\text {mean }}, \mathrm{T}_{\max }$ and $\mathrm{T}_{\min }>0{ }^{\circ} \mathrm{C}$; symbol $1-5$ ), frosty $\left(\mathrm{T}_{\max }>\right.$ $0{ }^{\circ} \mathrm{C}$ and $\mathrm{T}_{\min }<0{ }^{\circ} \mathrm{C}$; symbol 6-9) and freezing $\left(\mathrm{T}_{\max }\right.$ and $\mathrm{T}_{\min }<0^{\circ} \mathrm{C}$; symbol 10-12). Another group in the above classification is formed by weather subtypes, which contain information about cloudiness and diurnal precipitation. 

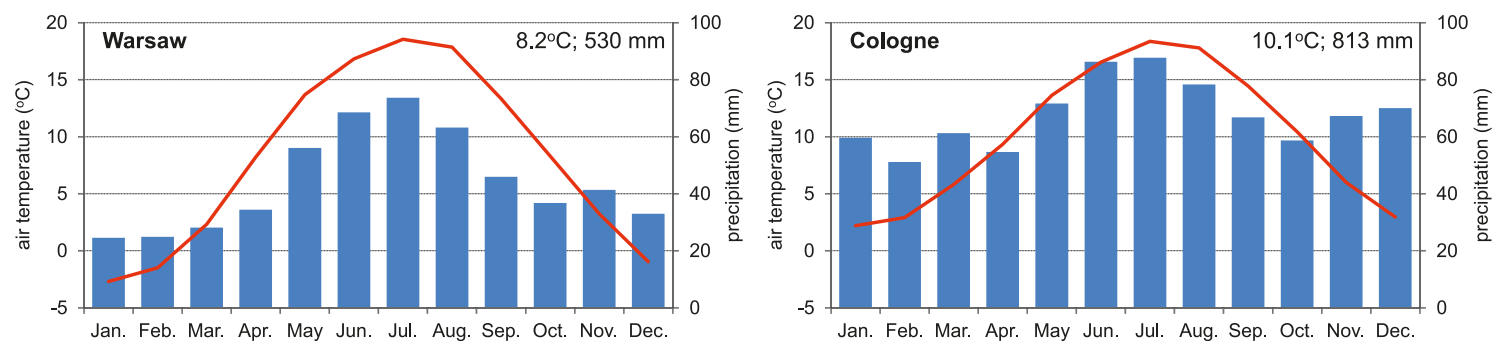

Fig. 1 Mean monthly and annual air temperature and precipitation totals in Warsaw and Cologne in the period 1961-2010

Woś (1999) also allowed for the identification of weather types with only some of the elements, such as temperature and cloudiness or temperature and precipitation, while others are missing, as well as for joining these elements to produce sets and groups of weather. The missing element is coded by a dash ("-"). For example, the type marked 2_- denotes very warm weather with an average daily temperature of $15.1-$ $25.0^{\circ} \mathrm{C}$ and both maximum and minimum temperature above $0{ }^{\circ} \mathrm{C}$; there is no data on cloudiness or precipitation.

The weather type classification system by Woś (1999) has been used by many researchers (see, for example, Bielec-Bąkowska and Piotrowicz, 2011; Kaszewski 1992; Piotrowicz 2010; Piotrowicz and Szlagor 2013; Piotrowicz and Ciaranek 2014). The system was also modified by adding an additional element (wind speed) and by altering the value ranges (Ferdynus and Marsz 2000). In this way, for example, it was possible to use the system to analyse the weather structure and climate seasonality in polar areas.
For comparison, the study also presents the results of analyses of the long-term variability and seasonal differences in thermal weather types distinguished by means of k-means cluster analysis. The method is based on grouping data into relatively homogeneous classes. Unlike the (a priori) method used by Woś (1999) to determine air temperature ranges, cluster analysis is perceived as a more objective method (Jolliffe and Philipp 2010; Hidalgo and Jougla 2018). It consists in entering data into a clustering algorithm, where the classes are created automatically (Jolliffe and Philipp 2010). The algorithm itself moves items into various clusters, seeking to minimize the variability inside clusters and to maximize that between particular clusters. The obtained result is a group of clusters with the greatest intra-cluster similarity and greatest inter-cluster variability. This method has been used for weather type classification by authors such as Hidalgo and Jougla (2018).

The present study uses $k$-means clustering, which enables the adoption of a predetermined number of classes. Thanks to this, the authors were able to compare the results obtained by both

Table 1 Weather type classification by Woś (1999)

\begin{tabular}{|c|c|c|c|}
\hline No & \multicolumn{2}{|c|}{ Partition } & Name of the days \\
\hline \multicolumn{4}{|c|}{ Air temperature (Thermal weather types) } \\
\hline 1 & $\mathrm{~T}_{\text {mean }}>25.0^{\circ} \mathrm{C}$ & \multirow{5}{*}{$\mathrm{T}_{\min } \& \mathrm{~T}_{\max }>0.0^{\circ} \mathrm{C}$} & hot \\
\hline 2 & $\mathrm{~T}_{\text {mean }} 15.1-25.0^{\circ} \mathrm{C}$ & & very warm \\
\hline 3 & $\mathrm{~T}_{\text {mean }} 10.1-15.0^{\circ} \mathrm{C}$ & & warm \\
\hline 4 & $\mathrm{~T}_{\text {mean }} 5.1-10.0^{\circ} \mathrm{C}$ & & moderately warm \\
\hline 5 & $\mathrm{~T}_{\text {mean }} 0.1-5.0^{\circ} \mathrm{C}$ & & cool \\
\hline 6 & $\mathrm{~T}_{\text {mean }}>5.0^{\circ} \mathrm{C}$ & \multirow{4}{*}{$\mathrm{T}_{\min } \leq 0.0^{\circ} \mathrm{C} ; \mathrm{T}_{\max }>0.0^{\circ} \mathrm{C}$} & ground-frost, moderately cool \\
\hline 7 & $\mathrm{~T}_{\text {mean }} 0.1-5.0^{\circ} \mathrm{C}$ & & ground-frost, very cool \\
\hline 8 & $\mathrm{~T}_{\text {mean }}-5.0-0.0^{\circ} \mathrm{C}$ & & ground-frost, moderately cold \\
\hline 9 & $\mathrm{~T}_{\text {mean }}<-5.0^{\circ} \mathrm{C}$ & & ground-frost, very cold \\
\hline 10 & $\mathrm{~T}_{\text {mean }}-5.0-0.0^{\circ} \mathrm{C}$ & \multirow{3}{*}{$\mathrm{T}_{\min } \& \mathrm{~T}_{\max } \leq 0.0^{\circ} \mathrm{C}$} & moderately frosty \\
\hline 11 & $\mathrm{~T}_{\text {mean }}-15.0 \div-5.1^{\circ} \mathrm{C}$ & & fairly frosty \\
\hline 12 & $\mathrm{~T}_{\text {mean }}<-15.0^{\circ} \mathrm{C}$ & & very frosty \\
\hline \multicolumn{4}{|c|}{ Cloudiness } \\
\hline $0-$ & $\mathrm{N} \leq 20 \%$ & & sunny or with little cloud amount \\
\hline $1-$ & N 21-79\% & & cloudy \\
\hline $2-$ & $\mathrm{N} \geq 80 \%$ & & very cloudy \\
\hline \multicolumn{4}{|c|}{ Precipitation } \\
\hline-0 & $\mathrm{P}<0.1 \mathrm{~mm}$ & & day without precipitation \\
\hline-1 & $\mathrm{P} \geq 0.1 \mathrm{~mm}$ & & day with precipitation \\
\hline
\end{tabular}

For example, 3_10 - warm, cloudy, without precipitation 
methods. Cluster analysis can be used to distinguish thermal weather types separately for each station, i.e. to apply different cluster ranges at given stations or, as it was done in this paper, to distinguish clusters taking into account the air temperature values for both stations simultaneously. This second approach makes it easier to compare and determine differences in values and seasonal temperature variability in both cities. However, the first approach is more effective when the aim of the study is to show the separateness of thermal conditions between stations. The different range of clusters makes it difficult to compare the temperature values and their seasonal variation between stations.

The air temperatures in the thermal weather types distinguished by cluster analysis are presented in Table 2 . The method of distinguishing weather subtypes is the same in both methods.

The study is not limited to the presentation of the annual and long-term variability (using the linear trend) of the identified types of weather. More detailed studies were conducted, including an analysis of the change of thermal weather types from one day to another. If the same type of weather was observed on several consecutive days, there was no change, meaning that the weather during the time was stable. Following this, strings of days with the same type of weather were counted for each year. The lower the number of such sequences, the longer they lasted, which meant that the weather was more stable.

\section{Annual and long-term variability of thermal weather types in Warsaw and Cologne}

The thermal weather types demonstrate a clear seasonal pattern (Fig. 2). The types, distinguished according to the Woś classification (Table 1), with the highest mean air temperature in excess of $25{ }^{\circ} \mathrm{C}$ (symbol 1), were sporadically recorded in Warsaw in the months from 29 May to 29 August. The very warm weather type (2) demonstrated the highest frequency during the year (Table 3 ). The potential period with a prevalence of this type of weather in the multiannual period under study was from April to October (Fig. 2). In Cologne, which is characterized by a more maritime climate, the hot (1), fairly frosty (11) and very frosty (12) weather types were less frequent (Table 2). On the other hand, ground-frost (6-9) and moderately warm days (4) were much more frequent than in Warsaw. Their potential periods of occurrence comprised: 28 May-28 August (1; only 2 days shorter than in Warsaw), 22 November6 March $(11 ; 36$ days shorter) and 1-18 January (12; in Warsaw 13 December-28 February) respectively (Fig. 2). Interestingly, for ground-frost (6-9) and moderately warm days (4), their periods of occurrence in both cities were very similar, while the frequency of their occurrence was by one-third lower in Warsaw. The annual trend of the thermal types of weather distinguished by means of clustering differed not only in the frequency but also in the period during the year during which they could potentially occur (Table 3, Fig. 2). However, the picture of seasonal differences in the thermal conditions at both stations using the two methods gives a range of interesting possibilities for the interpretation of the results. They can be used to identify thermal seasons of the year, make divisions into climatic regions with the same and/or different thermal conditions and identify the potential period of occurrence, the duration and sequence of the identified types, especially those that entail specific consequences for man and the natural environment.

The long-term changes in the thermal types of weather over the 50-year period illustrate the changeability of the climate in both cities very well (Fig. 3). Irrespective of the criterion used for the differentiation of thermal types of weather (1-12 or A-

Table 2 Frequency of occurrence (\%) of thermal weather types in Warsaw and Cologne in the period 1961-2010 determined using two classification methods and criteria for cluster analysis classification

\begin{tabular}{|c|c|c|c|c|c|c|c|c|}
\hline \multirow{3}{*}{ No } & \multirow{2}{*}{\multicolumn{2}{|c|}{$\begin{array}{c}\text { Frequency }(\%) \\
\text { Classification } \\
\text { by Woś }\end{array}$}} & \multirow{3}{*}{ No } & \multirow{2}{*}{\multicolumn{2}{|c|}{$\begin{array}{c}\text { Frequency }(\%) \\
\text { Cluster analysis } \\
\text { classification }\end{array}$}} & \multirow{2}{*}{\multicolumn{3}{|c|}{ Criteria for cluster analysis classification }} \\
\hline & & & & & & & & \\
\hline & Warsaw & Cologne & & Warsaw & Cologne & $T_{\text {mean }}$ & $T_{\max }$ & $T_{\min }$ \\
\hline 1 & 0.5 & 0.1 & A & 5.0 & 5.0 & $18.0-28.9$ & $24.6-38.8$ & $8.6-21.8$ \\
\hline 2 & 25.2 & 12.9 & B & 11.5 & 10.2 & $14.1-22.0$ & $20.9-30.3$ & $6.7-19.5$ \\
\hline 3 & 19.3 & 18.2 & $\mathrm{C}$ & 9.0 & 11.4 & $11.4-18.8$ & $15.3-23.3$ & $9.0-17.8$ \\
\hline 4 & 15.3 & 21.4 & $\mathrm{D}$ & 7.2 & 8.1 & $9.7-19.6$ & $17.9-27.4$ & $0.5-10.9$ \\
\hline 5 & 9.7 & 10.4 & $\mathrm{E}$ & 9.7 & 12.7 & $8.3-15.7$ & 11.4-20.3 & $5.0-13.2$ \\
\hline 6 & 1.4 & 3.5 & $\mathrm{~F}$ & 5.7 & 6.7 & $4.6-14.4$ & $11.7-22.2$ & $-3.7-6.5$ \\
\hline 7 & 9.9 & 16.4 & G & 8.2 & 12.2 & $4.5-11.5$ & $7.0-15.2$ & $1.0-10.0$ \\
\hline 8 & 7.4 & 9.7 & $\mathrm{H}$ & 10.7 & 14.5 & $1.2-8.8$ & $5.0-14.7$ & $-9.4-5.7$ \\
\hline 9 & 0.1 & 0.4 & I & 12.8 & 10.6 & $-3.2-5.4$ & $0.8-11.4$ & $-7.7-3.7$ \\
\hline 10 & 4.8 & 3.8 & $\mathrm{~J}$ & 10.7 & 6.0 & $-6.0-3.4$ & $-3.1-8.3$ & $-11.6-0.0$ \\
\hline 11 & 5.8 & 3.1 & K & 6.6 & 2.2 & $-10.0 \div-1.0$ & $\begin{array}{l}-7.6-7.0 \\
\end{array}$ & $-17.3 \div-4.6$ \\
\hline 12 & 0.5 & 0.1 & L & 2.8 & 0.4 & $-24.6 \div-6.3$ & $-20.2-0.3$ & $-30.7 \div-10.0$ \\
\hline
\end{tabular}




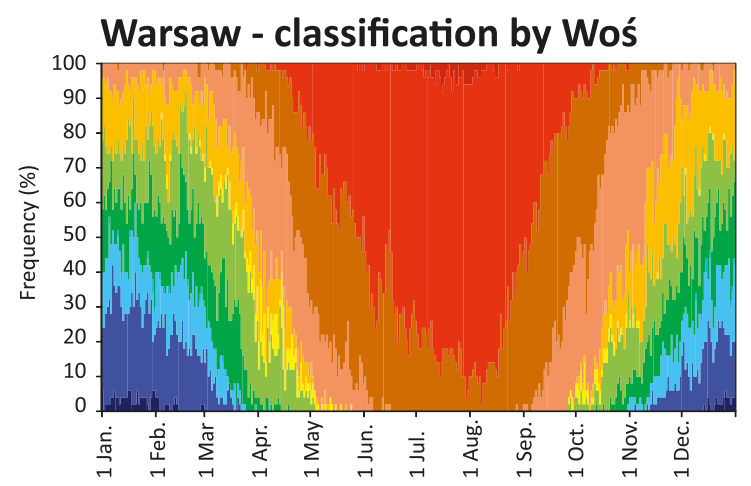

\section{Cologne - classification by Woś}
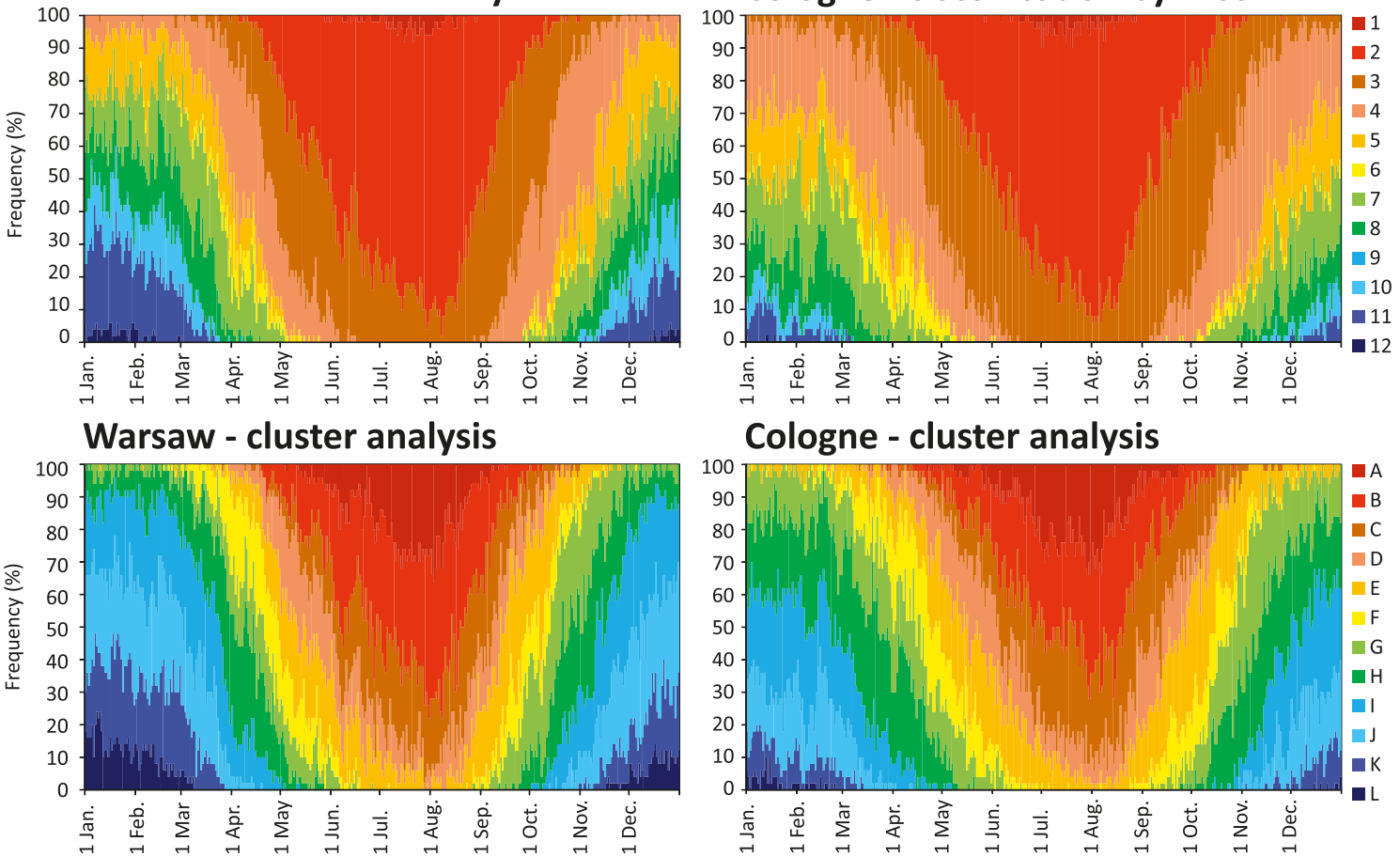

\section{Cologne - cluster analysis}

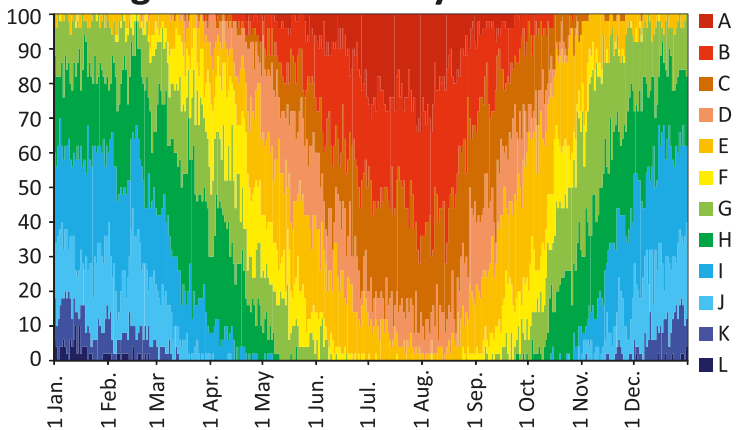

Fig. 2 Frequency $(\%)$ of occurrence of thermal weather types determined according to Woś' classification and clustering analysis in Warsaw and Cologne in the period 1961-2010 (explanation of the type numbers in Tables 1 and 2)

L; Tables 1 and 2), in recent years both Warsaw and Cologne have seen a decline in the frequency of fairly frosty (11 and $\mathrm{K})$, very frosty (12 and $\mathrm{L})$ and cool days (5 and $\mathrm{E})$ and an increase in hot and very warm days (1-2 and A-B).

\section{Stability of thermal weather types}

Figure 4 illustrates long-term changes in the number of day strings during the year using both classifications. As can be seen, Warsaw and Cologne saw a decrease in the number of sequences (statistically significant at $p<0.05$ ), which means a greater stability of thermal conditions according to the Woś classification (Fig. 4a). The drop in the number of day strings was caused by an increase in the number of hot (1) and/or very warm days (2) which occurred in longer several-day-long strings, and by a decrease in the number of moderately frosty (10) and fairly frosty (11) days occurring in isolation or in very short sequences of days. In case of the classification based on clustering, the trend was not statistically significant (Fig. 4b).

Table 3 Frequency (\%) of occurrence of weather types with the highest frequency of the year in Warsaw and Cologne in the period 1961-2010

\begin{tabular}{|c|c|c|c|c|c|c|c|}
\hline \multicolumn{4}{|l|}{ Classification by Woś } & \multicolumn{4}{|c|}{ Cluster analysis classification } \\
\hline \multicolumn{2}{|l|}{ Warsaw } & \multicolumn{2}{|l|}{ Cologne } & \multicolumn{2}{|l|}{ Warsaw } & \multicolumn{2}{|l|}{ Cologne } \\
\hline Type no (see Table 1) & $\%$ & Type no. (see Table 1) & $\%$ & Type no. (see Table 2) & $\%$ & Type no. (see Table 2) & $\%$ \\
\hline 2_10 & 12.6 & $2 \_10$ & 10.4 & B_10 & 5.9 & G_21 & 6.5 \\
\hline $3 \_10$ & 7.5 & 4_21 & 9.7 & I_21 & 5.3 & H_21 & 5.7 \\
\hline 2_11 & 6.2 & $3 \_21$ & 8.5 & D_10 & 3.9 & E_21 & 5.6 \\
\hline $4 \_10$ & 5.0 & $3 \_10$ & 7.2 & J_21 & 3.9 & C_21 & 4.7 \\
\hline $4 \_21$ & 4.8 & 2_11 & 6.1 & H_10 & 3.6 & B_10 & 4.5 \\
\hline 3_11 & 4.6 & 3_11 & 5.3 & C_10 & 3.5 & D_10 & 4.4 \\
\hline 5_21 & 4.5 & $2 \_21$ & 4.8 & E_10 & 3.2 & I_21 & 4.3 \\
\hline $3 \_21$ & 4.4 & 4_11 & 4.5 & H_21 & 3.1 & F_10 & 3.3 \\
\hline 2_00 & 3.5 & 4_10 & 4.2 & G_21 & 3.1 & H_11 & 3.3 \\
\hline Sum & 53.1 & Sum & 60.7 & Sum & 35.5 & Sum & 42.3 \\
\hline
\end{tabular}



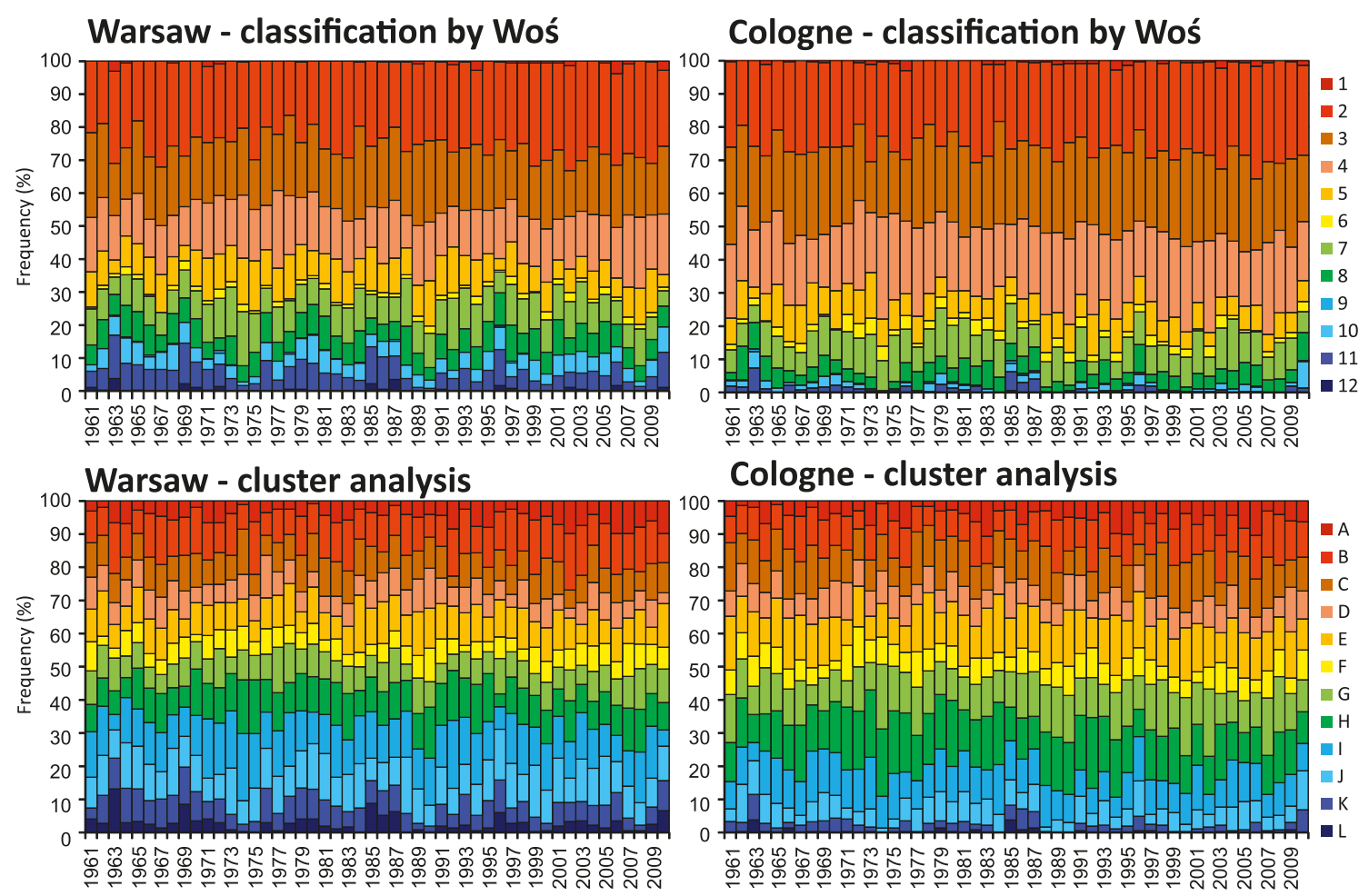

Fig. 3 Long-term variability of thermal weather types determined according to Woś classification and clustering analysis in Warsaw and Cologne in the period 1961-2010 (explanation of the type numbers in Tables 1 and 2)

The above conclusions are also confirmed by earlier studies by the authors (Ciaranek and Piotrowicz 2014), which focused on analysing the stability of thermal weather types in Central Europe. The lack of a statistically significant tendency of change in the stability of the thermal weather types identified using cluster analysis classification is linked to the fact that days with different values of air temperature (especially maximum and minimum values) were assigned to a very wide range of values (above and below $0{ }^{\circ} \mathrm{C}$; see Table 2, types $\mathrm{J}-\mathrm{L}$ ). The classification of thermal weather types based on clustering enables days with similar thermal conditions to be distinguished in a more objective manner, taking into account the natural variability of air temperature values at a given station. In recent years in winter (Dec.-Feb.), days with low air temperature values $(\mathrm{J}-\mathrm{K})$ were recorded in shorter strings

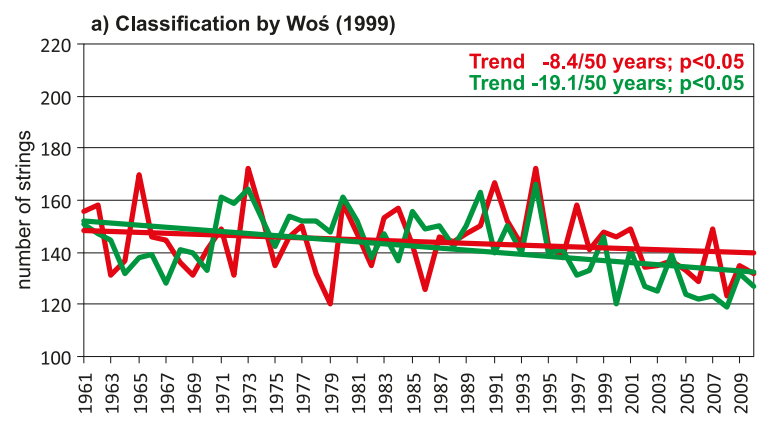

(thermal conditions in this season were unstable), while in summer (especially in July) and September the number of warm days (especially B) and their strings increased noticeably, which means that the weather was more stable.

\section{Weather subtypes and types}

As it has already been noted above, cloudiness and precipitation are necessary for distinguishing weather subtypes according to the classification proposed by Woś (1999) (Table 1). The first two digits (or one letter in cluster analysis classification), which indicate air temperature, are followed by two more digits, which stand for the range of cloudiness and the presence or absence of rainfall.

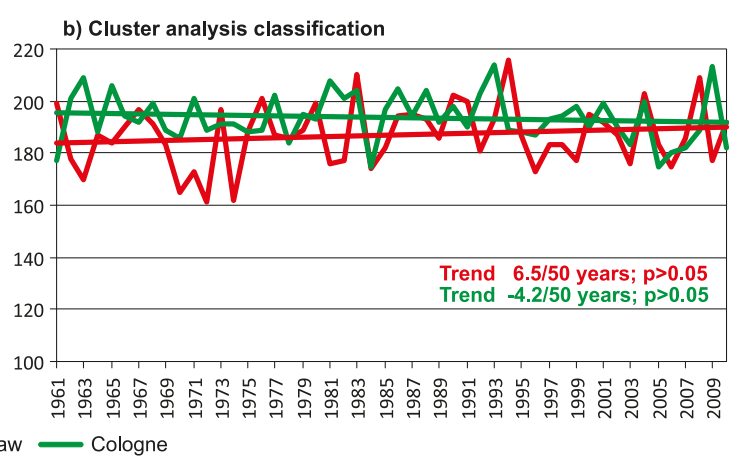

Fig. 4 Long-term variability of the annual number of strings of days according to the both thermal classifications (a Woś, b cluster analysis) in Warsaw and Cologne in the period 1961-2010 


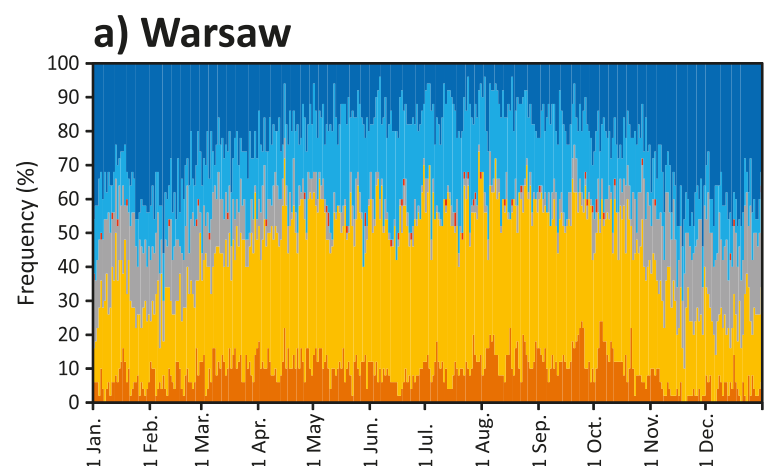

b) Cologne

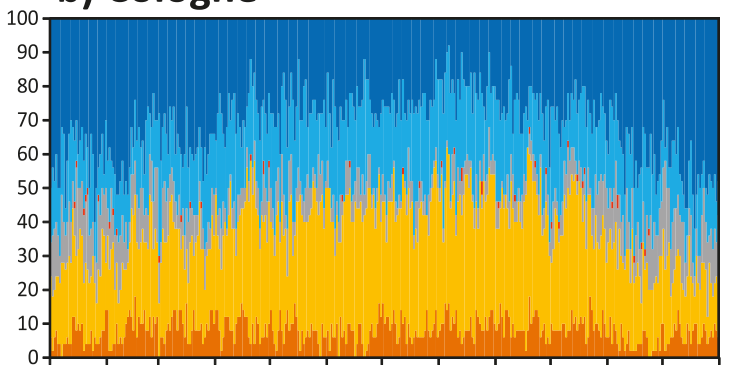

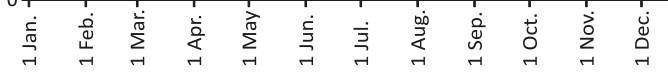
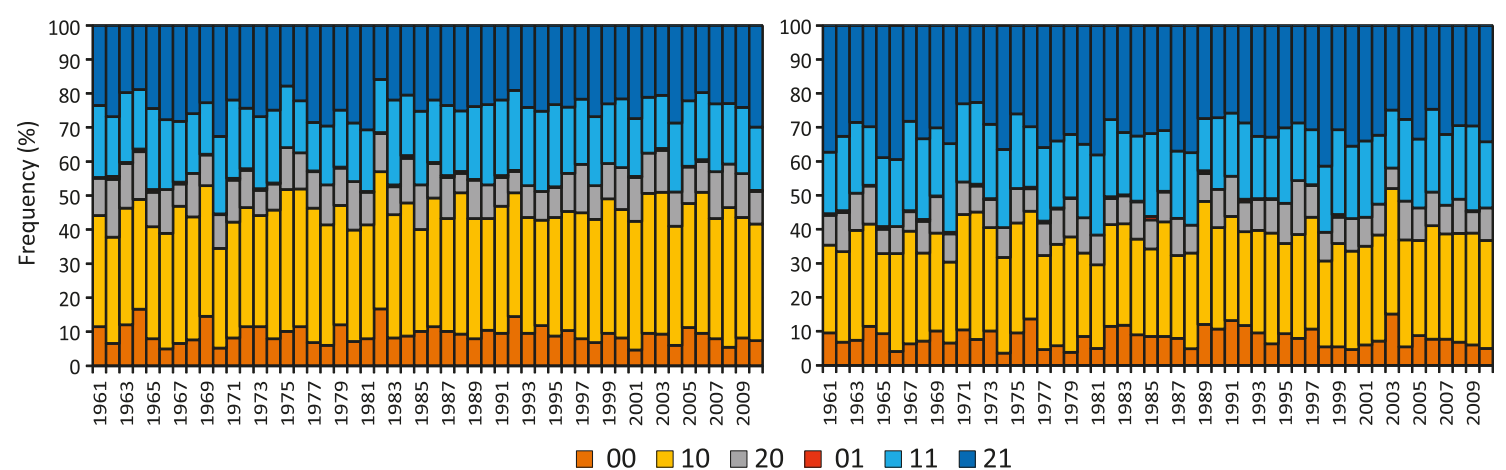

Fig. 5 Frequency (\%) of occurrence of weather subtypes in Warsaw and Cologne in annual and long-term course in the period 1961-2010 (explanation of the subtype numbers in Table 1)

The identified weather subtypes can occur throughout the year, although those marked with the symbol:

- _ 00 (sunny without precipitation) occur more often in April and August-October in Warsaw, and evenly throughout the year in Cologne,

- _ _10 (cloudy without precipitation) - in summer in Warsaw, and in April and September in Cologne,

- __11 (cloudy with precipitation) - in summer at both stations,

- _ _20 (very cloudy without precipitation) and -_21 (very cloudy with precipitation) - from November to February at both stations,

- _ _01 (sunny with precipitation) - occasionally in Warsaw and Cologne (Fig. 5).

In Warsaw and Cologne, the long-term weather subtypes (Fig. 5) saw a statistically significant $(p<0.05)$ increase in the number of days with weather -_10 (cloudy without precipitation; 15 days/50 years in Warsaw and 12 days/50 years in Cologne), which was mainly caused by a decrease in the number of days with sunny weather without and with precipitation $(-00$ and -01$)$, although their changes were not statistically significant $(p>0.05)$. The other weather subtypes showed no tendency of change in the multiannual period analysed (Fig. 5).

Table 3 shows the prevalence of the main types of weather in Warsaw and Cologne distinguished by reference to the three meteorological elements (temperature, cloudiness and precipitation). For air temperature, the division into weather types was made on the basis of two classifications-that by Woś (1999) and that relying on cluster analysis. As can be seen, air temperature is the most strongly differentiating factor for the weather types. As many as 9 of the dominant types of weather accounted for $53.1 \%$ in Warsaw and $60.7 \%$ in Cologne of all the days in the period under study. As regards the classification of weather types by cluster analysis, the differentiation of the weather types in the multiannual period was greater, since the 9 predominant weather types represented only $35.5 \%$ and $42.3 \%$ of all the types in the period under investigation (Table 3 ).

The weather differences in the period under study can also be examined by analysing the number of weather types in the individual years (Fig. 6). A lower number of weather types in a given year means that they form slightly longer series of days, which indicates greater weather stability. For Warsaw and Cologne, in the years 1951-2010, there was a statistically significant downward trend in the number of weather types, as distinguished by the cluster analysis method. Their number was particularly low in 1974 (47 in Warsaw and 39 in Cologne) and 2008 (respectively 47 and 40), which was caused by the fact that the winter that year was very warm (there were no days with temperatures in the last range-L, which usually form one/two-day strings) and summer was not very hot (there were only a few days with temperatures in the first range-A). On the other hand, days with the most 

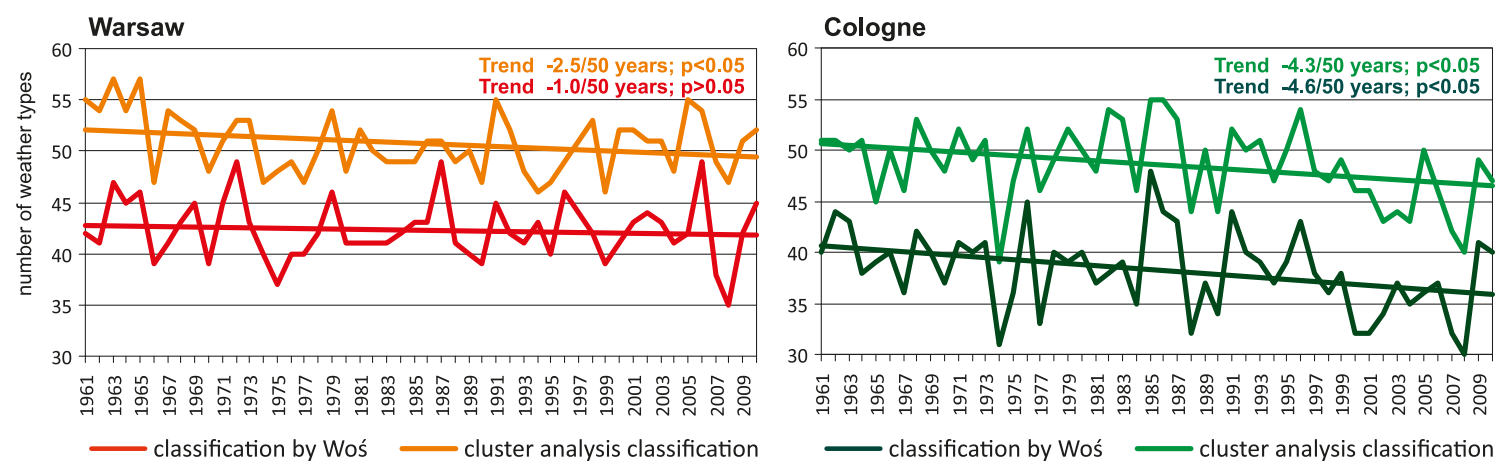

Fig. 6 Number of weather types in a multiyear course in Warsaw and Cologne in 1961-2010

frequent occurrence of weather types, especially $\mathrm{H} \_21$, I_21 and D_10, formed clearly longer sequences in the years under consideration. According to Woś' classification, there was also a statistically significant decrease in the number of weather types in Cologne (Fig. 6).

\section{Discussion and conclusions}

In this study, the aim was to discuss the most popular systems of weather type classification in climatological literature, and show examples of its application, using a classification by Woś (1999) and its modifications.

Weather type classification systems can be used in detailed studies of weather conditions, and also as basic information on climate variations during any period (month, season, year or long-term). It is important, however, to start by making a selection of the meteorological elements and classification criteria depending on the purpose of the study. As regards morphological weather type classifications, they most frequently rely on air temperature, precipitation, cloudiness and wind data (see Introduction). As emphasized by Hidalgo and Jougla (2018), the main advantage of the "climatological" approach to weather types, as opposed to "synoptic" weather types, is the fact that they refer directly to the description of the atmospheric situation resulting from an analysis of climatic data. Such analyses better reflect the local climate of a particular location and are hence better applicable to urban climate research (Hidalgo and Jougla 2018).

An element of subjectivity is always present in designing a classification (Hidalgo and Jougla 2018). It is involved in the selection of the meteorological elements and in the division of their values into ranges. Accusations of arbitrariness in the adopted classification criteria are virtually unavoidable. One must remember, however, that increasing the number of meteorological elements and their ranges leads to a growing number of weather types and makes subsequent analysis more difficult. In reality, the state of the weather varies enormously and can never be fully captured in quantitative/qualitative terms, but can only be approximated using certain features and grades of the weather elements selected. Therefore, while this classification system may raise many doubts, it can still be used to obtain interesting insights into the structure and variability of the climate in a given area. According to the authors, it is all the more possible since a comparison of thermal weather types identified using Woś' (a priori) method and using cluster analysis, considered to be an objective method (Hidalgo and Jougla 2018), gives comparable results.

In his classification, Woś set rigid ranges of meteorological element values based on the climatic conditions prevailing in the temperate zone. Therefore, the method can be used for studying the sequences of weather types in many areas, also those at a great distance from each other. A cluster analysis conducted for many stations simultaneously can likewise be used for comparison purposes, since in this case the ranges of values are the same for all the stations analysed. Of course, it is possible to distinguish weather types using cluster analysis for the values from each station separately, but then it is more difficult to compare the results between stations, especially if they are located in the same climate zone. However, it must be remembered that this method is an automatic one, and here weather types are also determined by taking the frequency of their occurrence into account.

Both methods of weather type recognition (by Woś and cluster analysis) have their good points and disadvantages. The analyses carried out in this work indicate that they give comparable results, among others in the case of long-term trends of thermal weather types and their stability. The main difference in the results obtained with the two methods lies in the fact that most weather types in the Woś classification can occur at specific times of year, while the weather types obtained by means of cluster analysis change more frequently during the year. Their greater diversity, compared with the Woś classification, can clearly be seen especially in the summer months.

The frequency of various weather types during multiyear periods and individual years, seasons or months can help in drafting a weather calendar. Such calendars can then be used in studies of extreme events. Calendars of weather conditions were performed in Poland by Błażejczyk (2004), Durło (2003a, b, c) and Piotrowicz (2010), among others. Those 
calendars are examples of studies that can be used for various purposes. Błażejczyk (2004) developed a calendar based on his own biothermal-meteorological weather classification. According to the author, the calendar gives the possibility to get information on the probable weather conditions helpful in planning outdoor recreation. Durło (2003a, b, c) has made three different calendars: (1) bioclimatic, presenting the temporal distribution of the suitability of weather types for various forms of human activity (recreation, tourism, climatotherapy) (Durło 2003a), (2) climatic, using the classification by Woś, with broad application in various areas (e.g. planning of field works, in forest management, gardening) (Durło 2003b) and (3) synoptic, developing that on the basis of the classification of circulation types (Durło 2003c). Piotrowicz (2010) has developed a calendar of weather types considering the frequency of the most common and extreme weather types in Krakow in the period 1901-2008. According to Cantat and Savouret (2014), rare combinations of weather types must be taken into consideration as days with such weather often entail environmental and/or human risks. A good example is the weather type described as warm, sunny with precipitation corresponding to a fine summer's day with a southerly wind, preceding the arrival of an active disturbance in the evening or of thunderstorms (Cantat and Savouret 2014), or days with last spring frost and first autumn frost (Tomczyk et al. 2015; Graczyk and Kundzewicz 2016).

Weather type classification systems, including the one proposed by Piotrowicz (2010), are useful in analysing weather anomalies. The author tested the impact such phenomena have on the environment and on humans by looking at specific cases of phenological emergence of plants and animals and on the timing of pollen seasons of certain plant taxons, including allergenic ones (e.g. grasses and birch tree). They can be useful in extending the utility of the proposed new methodological solutions and to determine the influence of climate change on a range of human activities and the environment in the temperate climate zone. According to Andrade et al. (2007), the classification of weather types can also be successfully used as a method to estimate the climate of touristic regions, especially since the climatic information is available for touristic purposes and usually comprises only the mean values of air temperature and precipitation. In turn, research by Hidalgo and Jougla (2018) suggests that weather typology can also be successfully used to analyse urban climate, for example: intensity, duration, frequency, shape and extension of the Urban Heat Island.

Thermal weather types by Woś $(1999,2010)$ were distinguished on the basis of threshold values corresponding to the majority of thermal seasons in Central Europe. Cluster analysis also makes it possible to distinguish "natural" seasons in a year. There are few papers in the climatology literature that address the problem of season distinction and their long-term variability. Among those papers, Jaagus and Ahas (2000),
Jaagus et al. (2003), Kożuchowski (2000) and Piotrowicz (2010) can be found. The seasons determined on the basis only of thermal or full weather types can be, like in Jaagus and Ahas (2000) and Jaagus et al. (2003), correlated with selected phenological phases of plants.

This classification system can also be used to analyse strings of days with the same weather type to determine its stability (permanence) and weather variability during the year. The identified increase in the frequency of days with hot and very warm weather, and the decrease in the number of days with fairly and very frosty weather in Warsaw and Cologne is are consistent with the results of studies by other authors concerning e.g. heat (Fenner et al. 2019) and cold waves (Smid et al. 2019).

Looking at the long-term variation of weather types that sometimes take the form of extreme events can supplement, or even help to verify existing theories on contemporary climate change or variability at a regional scale. This seems important both methodologically, in terms of understanding the climate, and for practical purposes in a range of areas such as agriculture, construction, transport, manufacturing and tourism. It was found on the basis of data from Warsaw and Cologne that between 1961 and 2010 in both cities there was a downward trend in terms of the number of weather types occurring during the year. This attests to the fact that within the 365 (or 366) days of the year, in the multiannual period, there was, on average a decreasing number of identified weather types, and consequently, those that did occur were grouped in longer series. This suggests a growing stability of weather in Europe. These results are consistent with studies about changes to thermal conditions in particular seasons of the year and overnight and with a decrease in the number of days with precipitation, coupled with an increase in the frequency of occurrence of periods without precipitation (Moberg and Jones 2005; Moberg et al. 2000). Also, weather types can be helpful in determining whether the contemporary weather variability was also observed in the past. The given examples of weather type analysis can be used with different classifications. It is useful to be familiar with the prevalence of weather types in the past, their consequences, and their seasonal and multiannual variations, for instance, while analysing their impact on human health and well-being, the economy, and the natural environment.

The stability of certain types of weather is extremely important because of the impact it can have on the natural environment, the human body and the economy. The adaptive mechanisms of organisms and plants respond differently when the same type of weather prevails over several days than when weather changes abruptly from one day to another. Even if the weather is stable, which tends to have a beneficial effect on the human body, the prevailing type of weather is also relevant. Longer spells of hot or extremely cold types of weather, which are strongly stimulating conditions, will not have a positive effect on human health and well-being, or on animals and plants. 
Open Access This article is licensed under a Creative Commons Attribution 4.0 International License, which permits use, sharing, adaptation, distribution and reproduction in any medium or format, as long as you give appropriate credit to the original author(s) and the source, provide a link to the Creative Commons licence, and indicate if changes were made. The images or other third party material in this article are included in the article's Creative Commons licence, unless indicated otherwise in a credit line to the material. If material is not included in the article's Creative Commons licence and your intended use is not permitted by statutory regulation or exceeds the permitted use, you will need to obtain permission directly from the copyright holder. To view a copy of this licence, visit http://creativecommons.org/licenses/by/4.0/.

\section{References}

Alcoforado MJ, Andrade H, Vieira Paulo MJ (2004) Weather and recreation at the Atlantic shore near Lisbon, Portugal: a study on applied local climatology. In: Matzarakis A, De Freitas CR, Scott D (eds) Advances in Tourism Climatology, pp 38-48

Andrade H, Alcoforado MJ, Oliveira S (2007) Methodologies to assess the effects of climate on tourism: weather type and individual perception. In: Matzarakis A, De Freitas CR, Scott D (eds) Developments in Tourism Climatology, pp 74-79

Besancenot JP, Mounier J, Lavenne J (1978) Les conditions climatiques du tourisme littoral: une méthode de recherche compréhensive. Norois 99:357-382

Bielec-Bąkowska Z, Piotrowicz K (2011) Weather types accompanying very high pressure in Krakow in the period 1901-2000. Int J Climatol 31:2183-2193

Bissolli P, Dittmann E (2001) The objective weather type classification of the German weather service and its possibilities of application to environmental and meteorological investigations. Meteorol $\mathrm{Z}$ 10(4):253-260

Błażejczyk K (1979) Typologia pogody na potrzeby klimatoterapii [Weather types for climatotherapy]. Dokum Geogr 2:12-24 (in Polish)

Błażejczyk K (1985) Bioklimatyczne typologie pogody [Bioclimatical typologies of weather]. Probl Uzdrow 1-2(207-208):80-91 (in Polish)

Błażejczyk K (2004) Bioklimatyczne uwarunkowania rekreacji i turystyki w Polsce [Bioclimatic principles of recreation and tourism in Poland]. Prace Geogr IGiPZ PAN 192:1-291 (in Polish)

Błażejczyk K, Matzarakis A (2007) Assessment of bioclimatic differentiation of Poland based on the human heat balance. Geogr Pol 80(1): 63-82

Boé J, Terray L (2008) A weather-type approach to analyzing winter precipitation in France: twentieth-century trends and the role of anthropogenic forcing. J Clim 21(13):3118-3133

Brown PR (2004) Weather types associated with extreme temperatures in England. Part 1: maximum temperatures. J Meteorol 29(294):358365

Brown PR (2005) Weather types associated with extreme temperatures in England. Part 2: minimum temperatures. J Meteorol 30(295):23-30

Cantat O, Savouret E (2014) A catalog of "weather types" in metropolitan France. Climatologie 11:65-71

Ciaranek D, Piotrowicz K (2014) Stability of thermal conditions in Central Europe. [in.] M. Kanakidou, N. Mihalopoulos, P. Nastos (eds), COMECAP, 12 International Conference of Meteorology, Climatology and Physics of the Atmosphere, 28-31 May 2014, Heraklion, University of Crete, Greece, 1:198-203

Durło G (2003a) Bioclimatic calendar a new form of climatological elaboration. Analele Univ din Oradea, Seria Geogr 13:99-104
Durło G (2003b) Kalendarz jako przykład opracowania klimatologicznego [Calendar as example of climatological elaboration]. Acta Sci Pol, Formatio Circumiectus 2(2):183-189 (in Polish)

Durło G (2003c) Kalendarz synoptyczny jako metoda opracowania klimatologicznego [The synoptic calendar as method of climatological elaboration]. Wiad IMGW 26(3):87-92 (in Polish)

Fenner D, Holtmann A, Krug A, Scherer D (2019) Heat waves in Berlin and Potsdam, Germany - long-term trends and comparison of heat wave definitions from 1893 to 2017. Int J Climatol 39:2422-2437

Ferdynus J, Marsz AA (2000), Struktura stanów pogód i sezonowość pogodowa [Structure of weather conditions and weather seasonality. [in] Główne cechy klimatu rejonu Polskiej Stacji Antarktycznej im. H. Arctowskiego (Antarktyka Zachodnia, Szetlandy Południowe, Wyspa Króla Jerzego) [Main climate features of the Polish Antarctic Station of Arctowski (West Antarctica, South Shetland Islands, King George Island)], A.A. Marsz and A. Styszyńska (eds). Wyższa Szkoła Morska, Gdynia, 143-162 (in Polish)

Graczyk D, Kundzewicz ZW (2016) Changes of temperature-related agroclimatic indices in Poland. Theor Appl Climatol 124:401-410

Hidalgo J, Jougla R (2018) On the use of local weather types classification to improve climate understanding: an application on the urban climate of Toulouse. PLoS One 13(12):1-21. e0208138. https://doi. org/10.1371/journal.pone. 0208138

Howe GF (1925) The summer and winter weather of selected cities in North America. Mon Weather Rev 10:427-429

Hufty A (1971) Les types de temps dans le Québec méridional-Méthode pédagogique de description des climats. Cah Geograph Quebec 15(34):29-52. https://doi.org/10.7202/020942ar

Jaagus J, Ahas R (2000) Space-time variations of climatic seasons and their correlation with the phenological development of nature in Estonia. Clim Res 15(3):207-219

Jaagus J, Truu J, Ahas R, Aasa A (2003) Spatial and temporal variability of climatic seasons on the East European Plain in relation to largescale atmospheric circulation. Clim Res 23(2):111-129

Jolliffe IT, Philipp A (2010) Some recent developments in cluster analysis. Phys Chem Earth 35:309-315

Kaszewski BM (1992) Typy cyrkulacji a typy pogody w Polsce [Circulation types and weather types in Poland]. Rozprawy Habilitacyjne Wydziału Biologii i Nauk o Ziemi UMCS, 42, Lublin (in Polish)

Klein Tank AMG, Wijngaard JB, Können GP et al (2002) Daily dataset of 20th-century surface air temperature and precipitation series for the European Climate Assessment. Int J Climatol 22:1441-1453

Kozłowska-Szczęsna T (1965) New soviet publications in the field of complex climatology. Int J Biometeorol 9(5):261-265

Kożuchowski K (ed.) (2000) Pory roku w Polsce, sezonowe zmiany w środowisku a wieloletnie tendencje klimatyczne, Łódź (in Polish)

Littmann T (2000) An empirical classification of weather types in the Mediterranean Basin and their interrelation with rainfall. Theor Appl Climatol 66:161-171

Maheras P (1984) Weather-type classification by factor analysis in the Thessaloniki area. J Climatol 4(4):437-443

Maheras P (1985) Correspondences between types of circulation and weather types. Application to the area of Thessaloniki. Z Meteorol 35(1):26-35

Makra L, Mika J, Bartzokas A, Béczi R, Sümeghy Z (2009) Comparison of objective air-mass types and the Péczely weather types and their ability to classify levels of air pollutants in Szeged, Hungary. Int J Environ Pollut 36(1-3):81-98

Michailidou C, Maheras P, Arseni-Papadimititriou A, Kolyva-Machera F, Anagnostopoulou C (2009a) A study of weather types at Athens and Thessaloniki and their relationship to circulation types for the coldwet period, part I: two-step cluster analysis. Theor Appl Climatol 97(1-2):163-177

Michailidou C, Maheras P, Arseni-Papadimititriou A, Kolyva-Machera F, Anagnostopoulou C (2009b) A study of weather types at Athens and 
Thessaloniki and their relationship to circulation types for the coldwet period, part II: discriminant analysis. Theor Appl Climatol 97(1-2):179-194

Moberg A, Jones PD (2005) Trends in indices for extremes in daily temperature and precipitation in Central and Western Europe analyzed 1901-1999. Int J Climatol 25:1149-1171

Moberg A, Jones PD, Barriendos M, Bergström H, Camuffo D, Cocheo C, Davies TD, Demarée G, Martin-Vide J, Maugeri M, Rodriguez $\mathrm{R}$, Verhoeve T (2000) Day-to-day temperature variability trends in 160-to 275-year-long European instrumental records. J Geophys Res Atmos 105:22849-22868

Moron V, Robertson AW, Ward MN, Ndiaye O (2008) Weather types and rainfall over Senegal. Part I: observational analysis. J Clim 21(2): 266-287

Nichols ES (1925) A classification of weather types. Mon Weather Rev 10:431-434

Nichols ES (1927) Frequencies of weather types at San Jose. Mon Weather Rev 9:403-405

Philipp A, Bartholy J, Beck C, Erpicum M, Esteban P, Fettweis X, Huth R, James P, Jourdain S, Kreienkamp F, Krennert T, Lykoudis S, Michalides SC, Pianko-Kluczynska K, Postm P, Álvarez DR, Schiemann R, Spekat A, Tymvios FS (2010) Cost733cat - a database of weather and circulation type classifications. Phys Chem Earth 35:360-373

Piotrowicz K (2010) Sezonowa i wieloletnia zmienność typów pogody w Krakowie [Seasonal and long-term weather type variability in Krakow]. IGiGP UJ, Krakow (in Polish)

Piotrowicz K, Ciaranek D (2014) The impact of weather types on air pollution and health of the residents of Krakow (Poland). In: Air and weather components of the environment. Cluj University Press, Romania, pp 40-47
Piotrowicz K, Szlagor J (2013) The link between from day to day change of weather types and synoptic situations in Kraków during the period 1961-2010. Quaest Geogr 32(3):69-84

Putniković S, Tošić I (2018) Relationship between atmospheric circulation weather types and seasonal precipitation in Serbia. Meteorog Atmos Phys 130:393-403. https://doi.org/10.1007/s00703-0170524-y

Schwander M, Brönnimann S, Delaygue G, Rohrer M, Auchmann R, Brugnara Y (2017) Reconstruction of Central European daily weather types back to 1763. Int J Climatol 37:30-44

Sheridan SC (2002) The redevelopment of a weather-type classification scheme for North America. Int J Climatol 22(1):51-68

Sheridan SC (2003) North American weather-type frequency and teleconnection indices. Int J Climatol 23(1):27-45

Smid M, Russo S, Costa AC, Granell C, Pebesma E (2019) Ranking European capitals by exposure to heat waves and cold waves. Urban Clim 27:388-402

Switzer J (1925) Weather types in the climate of Mexico, The Canal Zone, and Cuba. Mon Weather Rev 10:434-437

Tomczyk AR, Szyga-Pluta K, Majkowska A (2015) Frost periods and frost-free periods in Poland and neighbouring countries. Open Geosci 7:812-823. https://doi.org/10.1515/geo-2015-0061

Woś A (1999) Klimat Polski [climate of the Poland]. PWN, Warszawa (in Polish)

Woś A (2010) Klimat Polski w drugiej połowie XX wieku [climate of Poland in the second half of the $20^{\text {th }}$ century]. Wydawnictwo Naukowe UAM, Poznań (in Polish)

Publisher's note Springer Nature remains neutral with regard to jurisdictional claims in published maps and institutional affiliations. 